\title{
An Effect of Perceived Usefulness and User's Attitude to the Intention of Using the Technology-Based Cost of Production Calculation System
}

\author{
Chalarce Totanan \\ Tadulako University \\ chalarce@untad.ac.id
}

\author{
Rahayu Indriasari \\ Tadulako University
}

\author{
Supriadi Laupe \\ Tadulako University
}

\begin{abstract}
This study aims to examine and analyze the effect of perceived usefulness and user's attitude to the intention of using the technology-based cost of production calculation system (HPP) in the course of cost accounting. The test was performed by using simple linear regression analysis and moderation regression analysis. The results showed that the perceived usefulness and user's attitude affected the interest in using technology-based cost of production calculation system in learning process, especially in cost accounting courses.
\end{abstract}

Keywords: cost accounting, learning method, and information systems.

\section{INTRODUCTION}

The existence and development of technology, especially computers in higher education, is expected to improve the performance of all parties involved with the college in general [1]. [2]-[3] stated that at this time lecturers are required to be able to touse (touse gak ada di kamus) computer properly because it can be used as a tool to facilitate teaching and learning activities and make a learning process more interesting, easier, fun, and varied.

Law of the Republic of Indonesia Number 18 Year 2002 concerning the National System of Research, Development, and Application of Science and Technology Article 7, paragraph 1 mandates the college as one of the institutional elements to function in the form of human resources, science, and technology. Thus, universities must be able to produce a professional accountant who has knowledge and skills, including mastery of information technology.

The use of information technology in teaching and learning now becomes a necessity in the rapid development of information technology itself. However, the use of information technology is actually still limited to the faculty activities as teachers and students have not yet touched on the subject despite the accounting computer. But it seems that this does not meet the needs of students in facing competition. Therefore, we need a method or system of learning to meet these needs by using information technology in teaching and learning.
The qualified curriculum used as a guide by students taking Accounting Undergraduate Program is required to provide them good skills and professionalism to compete in the competitive job world. A Handbook of Academic Researchers found a rule that a student of Accounting Undergraduate Program must take at least 144 Semester Credit Units (SKS). These credits include 12 credits of practicum, but unfortunately practicum is still held manually. That is why it requires innovation to make developed teaching methods as the development of information technology.

One of the subjects that is implemented both theoretically and practically is accounting cost. This course is taken by students in semester 3 with the proviso has passed Introduction to Accounting 2, and cost accounting practicum in semester 4 with the proviso has passed Cost Accounting. However, the learning method is still done by hand, so it encourages researchers to develop a teaching method course, especially technology-based Cost Accounting in the cost of production calculation.

In accordance with the draft of Learning Tool (RPP) and Unit Events Teaching (SAP), the purpose of learning or competence of an accounting class fees is to make students able to take advantage of cost information for planning and controlling the allocation of economic resources company and manipulate information about the cost to meet the needs of management planning and control activities of the company. Specifically, the purpose of cost accounting learning is students are able to understand and calculate the Cost of Production (HPP). They can calculate the cost of the manual method that less meets the needs of today's students to the amount of data that does not allow to be counted manually. It also needs information technology that cannot be avoided.

A phenomenon that occurs in the learning process, especially in the calculation of the HPP, is that the students are difficult to understand the method of calculation of the HPP. It can be seen from the results of the midterms which are still low around 30-60. So, we need an interesting and easy method of learning for students. One way that can be done is to develop technology-based learning method. The development of technology-based learning method uses the tools of the 
calculation prototype of Production Cost-basedtechnology (HPP). It aims to facilitate students and faculty in calculating HPP. However, it is necessary to test the acceptance of the use of the system (faculty and students) because the system developed will not succeed if it is not acceptable to users [4]. This study will test the acceptance of the system such as perceived usefulness and user's attitude to the interest of using the technologybased calculation system (HPP).

\section{METHOD}

This research is a case study. The user's acceptance was used to test this system in terms of faculty and students using technology acceptance model (Technology Acceptance Model or TAM) [5]. This test examined the effect of perceived usefulness to the interest of using technology-based calculation system (HPP) and whether the user's attitude moderated the perceived usefulness to the interest of using technologybased calculation system (HPP). The purpose of this test was to test whether the perceived usefulness and user's attitude affect the interest of using technology-based calculation system (HPP) in the learning process, especially in the subject of cost accounting. In the test phase system, the data were collected through observation and interview. At this research stage, is a trial was done to observe implementation technologybased accounting system (HPP). Interview was conducted to understand the technology-based calculation system (HPP) implemented and to identify and revise the weaknesses that appear on the system by having Q\&A and student discussion in accounting class cost, practical cost accounting, lecturer of the course cost accounting, and lab cost accounting. The required data on user's acceptance testing HPP calculation system based on this technology were collected through questionnaire method. It was part of the TAM, [6] User's acceptance testing technology-based accounting system (HPP) was tested by using simple regression analysis statistical method in partial least square (PLS) with Smart PLS program ver. $2.0 \mathrm{M} 3$.

\section{RESULTS AND DISCUSSION}

Questionnaires distributed in this study were $100 \%$. Nevertheless, only $94 \%$ was eligible to be processed while $6 \%$ was not because the respondents chose two answers in a statement. The respondents in this study consisted of students and lecturers courses cost accounting. Based on the validity of the test, the results of the correlations between each question were correlated to the value of the total score indicating greater results compared to the value of $r$ table. So, the questionnaire items was considered valid. In terms of reliability, the coefficients of Cronbach alpha, of 0.7 or greater, the research instrument was considered reliable.

The equation model of simple linear regression analysis and moderation regression analysis in this study fulfilled three classical assumptions: no multicollinearity, no heteroscedasticity, and the data had a normal distribution. ANOVA test $\mathrm{F}$ test showed a value of 32.3 with a significance level of 0.000 . Therefore, the probability of significance was much lower than 0.05 , then the regression model was used to predict interest in using production cost price calculation system based on technology.

Next, it obtained $t$ value of 4,442. It explained the partial effect of perceived usefulness to the interest of using technology-based calculation system (HPP). $R$ square value in this study showed a value of $28.9 \%$. Thus, it explained that the variation/change of the interest of using technology-based calculation system (HPP) based on the variables of perceived usefulness and user's attitude was only $28.9 \%$ while the rest of $71.1 \%$ was explained by other variables.

Testing using the moderation regression analysis with a value of $R$ square showed the value of 0.323 . It meant only $32.3 \%$ of the independent variables could describe the dependent variables. Thus, we can say that perceived usefulness will determine a person's attitude and interest in using production cost price calculation system technology based on cost accounting subjects.

Directions regression significant standardized coefficients in this study showed that perceived usefulness and user's attitude was the deciding factor for someone to have interest in using technology-based calculation system (HPP). It meant how much the perceived usefulness as well as user attitudes was would affect the desire and willingness to use technology-based systems in the learning process. This finding supported studies conducted by [8] which stated that the greater benefits perceived by users of the system would determine the attitude and interests of a person to use the system. Users of the system would look at the perceived benefits in using the system. If the system would bring benefits then they would determine their attitude and interest for using or not using the system.

The results of this study were also consistent with research conducted by [7] which stated that attitude and a person's interest in using the system would be affected by how big the benefits provided by the system. In this study, the system in question was a production cost price calculation system based on technology. As we know, one of the subjects that must be taken by students majoring in accounting was cost accounting subject. Based Learning Tool Plan (RPS) is an item in accounting subjects to calculate the cost of production (HPP). In the process of teaching and learning, there are still many students who are difficult to calculate the HPP in particular manual. This system is designed to help and facilitate students and lecturers in calculating the HPP, especially in the course of cost accounting. This study has successfully tested and found that the perceived usefulness and user's attitude affected the interest in using the technology-based cost of production calculatin systems in the learning process, especially in cost accounting courses. 


\section{REFERENCES}

[1] Al Fatta, H. Analisis dan Perancangan Sistem Informasi untuk Keunggulan Bersaing Perusahaan dan Organisasi Modern. Andi Offset. Yogyakarta. 2007.

[2] Bodnar, H.G. dan Hopwood. S.W. Sistem Informasi Akuntansi. Edisi 9. Penerbit Andi. Yogyakarta. 2006.

[3] Bailey, J.E., and Pearson, S.W. Development ofa Tool for Measuring and Analyzing Computer User Satisfaction, Management Since, (29:5), pp. 530-54. 1983.

[4] Beach, LR. and Mitchell, TR. A Contingency Model forthe Selection of Decision Strategies, Academy Of Management Review, July. 1978.
[5] Chau, P.Y.K. An Empirical Assessment ofa Modified Technology Acceptance Model, Journal of Management Information System, pp. 185-204. 1996.

[6] Chiu, Chao-Min, Chiu Chao-Sheng and Chang Hae-Ching. Examining the Integrated Influence of Fairness and Quality on Learners Satisfaction and Web-Based Learning Continuance Intention, System Information Journal Blackwell Publishing Ltd, Volume 17, pp. 271-28. 2007.

[7] Carter.and Yusry. Akuntansi Biaya, Edisi Tiga Belas, Salemba Empat, Jakarta. 2005.

[8] Davis, F.D. Perceived Usefulness, Perceived Ease of Use, And User Acceptance of Information Technology, MIS Quarterly(13), pp. 319-34.1989. 